\title{
Osteohistology of Late Triassic prozostrodontian cynodonts from Brazil
}

\author{
Jennifer Botha-Brink ${ }^{\text {Corresp., }}{ }^{1,2}$, Marina Bento Soares ${ }^{3}$, Agustín G Martinelli ${ }^{3}$ \\ ${ }^{1}$ Karoo Palaeontology, National Museum, Bloemfontein, South Africa \\ 2 Department of Zoology and Entomology, University of the Free State, Bloemfontein, South Africa \\ 3 Departamento de Paleontologia e Estratigrafia, Instituto de Geociências, Universidade Federal do Rio Grande do Sul, Porto Alegre, Brazil \\ Corresponding Author: Jennifer Botha-Brink \\ Email address: jbotha@nasmus.co.za
}

The Prozostrodontia includes a group of Late Triassic-Early Cretaceous eucynodonts plus the clade Mammaliaformes, in which Mammalia is nested. Analysing their growth patterns is thus important for understanding the evolution of mammalian life histories. Obtaining material for osteohistological analysis is difficult due to the rare and delicate nature of most of the prozostrodontian taxa much of which comprises mostly crania or sometimes even only teeth. Here we present a rare opportunity to observe the osteohistology of several postcranial elements of the basal prozostrodontid Prozostrodon brasiliensis, the tritheledontid Irajatherium hernandezi, and the brasilodontids Brasilodon quadrangularis and Brasilitherium riograndensis from the Late Triassic of Brazil (Santa Maria Supersequence). Prozostrodon and Irajatherium reveal similar growth patterns of rapid early growth with annual interruptions later in ontogeny. These interruptions are associated with wide zones of slow growing bone tissue. Brasilodon and Brasilitherium exhibit a mixture of woven-fibered bone tissue and slower growing parallel-fibered and lamellar bone. The slower growing bone tissues are present even during early ontogeny. The relatively slower growth in Brasilodon and Brasilitherium may be related to their small body size compared to Prozostrodon and Irajatherium. These brasilodontids also exhibit osteohistological similarities with the Late Triassic/Early Jurassic mammaliaform Morganucodon and the Late Cretaceous multituberculate mammals Kryptobaatar and Nemegtbaatar. This may be due to similar small body sizes, but may also reflect their close phylogenetic affinities as Brasilodon and Brasilitherium are the closest relatives to the Mammaliaformes. However, when compared with similar-sized extant placental mammals, they may have grown more slowly to adult size as their osteohistology shows it took more than one year for growth to attenuate. Thus, although they exhibit rapid juvenile growth, the small derived, brasilodontid prozostrodontians still exhibit an extended growth period compared to similar-sized extant mammals. 


\section{Osteohistology of Late Triassic prozostrodontian cynodonts from Brazil}

2

3 Jennifer Botha-Brink*,1, Marina Bento Soares ${ }^{2}$, and Agustín G. Martinelli ${ }^{2}$

4

$5{ }^{1}$ P. O. Box 266, Department of Karoo Palaeontology, National Museum, Bloemfontein, 9300,

6 South Africa, and Department of Zoology and Entomology, University of the Free State,

7 Bloemfontein, 9300, South Africa, jbotha@nasmus.co.za;

$8{ }^{2}$ Departamento de Paleontologia e Estratigrafia, Instituto de Geociências, Universidade Federal

9 do Rio Grande do Sul, Porto Alegre, Brazil, marina.soares@ufrgs.br,

10 agustin_martinelli@yahoo.com.ar

$24 *$ Corresponding author: Jennifer Botha-Brink, Email: jbotha@nasmus.co.za 25 ABSTRACT 
26 The Prozostrodontia includes a group of Late Triassic-Early Cretaceous eucynodonts plus the

27 clade Mammaliaformes, in which Mammalia is nested. Analysing their growth patterns is thus

28 important for understanding the evolution of mammalian life histories. Obtaining material for

29 osteohistological analysis is difficult due to the rare and delicate nature of most of the

30 prozostrodontian taxa much of which comprises mostly crania or sometimes even only teeth.

31 Here we present a rare opportunity to observe the osteohistology of several postcranial elements

32 of the basal prozostrodontid Prozostrodon brasiliensis, the tritheledontid Irajatherium

33 hernandezi, and the brasilodontids Brasilodon quadrangularis and Brasilitherium riograndensis

34 from the Late Triassic of Brazil (Santa Maria Supersequence). Prozostrodon and Irajatherium

35 reveal similar growth patterns of rapid early growth with annual interruptions later in ontogeny.

36 These interruptions are associated with wide zones of slow growing bone tissue. Brasilodon and

37 Brasilitherium exhibit a mixture of woven-fibered bone tissue and slower growing parallel-

38 fibered and lamellar bone. The slower growing bone tissues are present even during early

39 ontogeny. The relatively slower growth in Brasilodon and Brasilitherium may be related to their

40 small body size compared to Prozostrodon and Irajatherium. These brasilodontids also exhibit

41 osteohistological similarities with the Late Triassic/Early Jurassic mammaliaform

42 Morganucodon and the Late Cretaceous multituberculate mammals Kryptobaatar and

43 Nemegtbaatar. This may be due to similar small body sizes, but may also reflect their close

44 phylogenetic affinities as Brasilodon and Brasilitherium are the closest relatives to the

45 Mammaliaformes. However, when compared with similar-sized extant placental mammals, they

46 may have grown more slowly to adult size as their osteohistology shows it took more than one

47 year for growth to attenuate. Thus, although they exhibit rapid juvenile growth, the small 
48 derived, brasilodontid prozostrodontians still exhibit an extended growth period compared to

49 similar-sized extant mammals.

50

\section{INTRODUCTION}

52 The non-mammaliaform cynodonts are the most derived and mammal-like clade of non-

53 mammalian synapsids (Therapsida). They first appeared during the late Permian (Botha, Abdala

54 and Smith, 2007; Kammerer, 2016) and were relatively rare components of Permian ecosystems

55 until after the Permo-Triassic mass extinction (Hopson and Kitching, 2001; Abdala and Ribeiro,

56 2010), when they radiated rapidly into a diverse clade with an increasingly mammalian

57 morphology (Luo, 2007). The Triassic non-mammaliaform eucynodonts diverged into two major

58 lineages, the Cynognathia and Probainognathia (Hopson and Kitching, 2001). Within the

59 Cynognathia, a group of large-bodied herbivorous/omnivorous taxa known as the Gomphodontia

60 arose during the Middle Triassic. This clade includes the families Diademodontidae,

61 Trirachodontidae and Traversodontidae (Crompton, 1955; Hopson and Kitching, 2001; Abdala,

62 2007). The latter group includes highly diverse, globally distributed non-mammaliaform

63 cynodonts that became especially abundant during the Late Triassic, with an apomorphic

64 masticatory system for cutting and grinding food (Abdala and Ribeiro, 2010). The

65 Probainognathia appeared during the early Late Triassic and gave rise to the Prozostrodontia, a

66 clade that became progressively smaller-bodied during its evolution before evolving into crown

67 group mammals during the Early Jurassic (Liu and Olsen, 2010; Ruta et al., 2013; Martinelli and

68 Soares, 2016). The non-mammaliaform prozostrodontians illustrate the prior steps to the rise of

69 Mammaliaformes and are thus, important for understanding the origin and evolution of

70 mammals. The Prozostrodontia contain several unranked taxa (e.g., Prozostrodon, 
71 Therioherpeton, Alemoatherium, Botucaraitherium), as well as two well-known major clades,

72 the Tritylodontidae and Tritheledontidae, both closely related to Mammaliaformes (Hopson and

73 Kitching, 2001; Liu and Olsen, 2010; Soares, Martinelli and Oliveira, 2014; Martinelli et al.,

$742017 \mathrm{a}, \mathrm{b}$ ). The Tritylodontidae are a group of medium-sized (basal skull length, BSL $\sim 50-250$

$75 \mathrm{~mm}$ ) highly specialized herbivorous prozostrodontians that arose during the Late Triassic and

76 went extinct during the Early Cretaceous (e.g., Clark and Hopson, 1985; Sues, 1986; Matsuoka,

77 Kusuhashi and Corfe, 2016). The Tritheledontidae are a group of small (BSL $\sim 30-70 \mathrm{~mm}$ ),

78 faunivorous/frugivorous forms that existed from the Late Triassic to Early Jurassic (Kemp, 2005;

79 Gow, 1980; Martinelli et al., 2005; Martinelli and Rougier, 2007; Soares, Schultz and Horn,

80 2011).

81 There has been much debate regarding which group is more closely related to mammals

82 as both groups have derived cranial and postcranial features typical of Mammaliaformes that

83 reveals different topologies according to different phylogenetic hypotheses (e.g., Luo, 1994;

84 Hopson and Kitching, 2001; Kemp, 2005; Abdala, 2007). However, more recently discovered

85 taxa from Brazil (i.e., Brasilodon quadrangularis, Brasilitherium riograndensis, Minicynodon

86 maieri, Botucaraitherium belarminoi; Bonaparte et al., 2003, 2010; Bonaparte, Martinelli and

87 Schultz, 2005; Bonaparte, Soares and Martinelli, 2012; Soares, Martinelli and Oliveira, 2014)

88 show a closer relationship to Mammaliaformes than the aforementioned groups (Bonaparte,

89 Martinelli and Schultz, 2005; Soares, Martinelli and Oliveira, 2014; Martinelli et al., 2017a, b).

90 Some of these species were grouped into Brasilodontidae (Bonaparte, Martinelli and Schultz,

91 2005), but their monophyly and composition (e.g., Bonaparte, 2013) should be tested more

92 comprehensively, as well as the taxonomic validity of some of the members (see Liu and Olsen,

93 2010; Martinelli and Bonaparte, 2011; Martinelli, 2017). These tiny (BSL approximately 20-55 
$94 \mathrm{~mm}$ ) faunivorous/frugivorous animals lived during the Late Triassic and have a set of derived

95 features (e.g., "triconodont"-like dentition, lack of a postorbital bar, slender horizontal ramus of

96 the dentary and zygomatic arch, petrosal with a promontorium) that is not seen in any other non-

97 mammaliaform cynodont, making them important taxa for understanding the early evolution of

98 Mammaliaformes (Kemp, 2005; Bonaparte, Martinelli and Schultz, 2005; Bonaparte, Soares and

99 Martinelli, 2012; Bonaparte, 2013; Rodrigues, Ruf and Schultz, 2013, 2014).

100 The South American non-mammaliaform prozostrodontians and closely related forms

101 (e.g., Protheriodon, Candelariodon) are particularly noteworthy as several important finds have

102 shed light on the morphological changes that occurred prior to and during the evolution of the

103 Mammaliaformes (Bonaparte and Barberena, 2001; Bonaparte, Martinelli and Schultz, 2005;

104 Soares, Schultz and Horn, 2011; Rodrigues, Ruf and Schultz, 2013; Martinelli, Soares and

105 Schwanke, 2016; Martinelli et al., 2017a, b). This remarkable record includes about 20 species of

106 probainognathians (ecteniniids, chiniquodontids, probainognathids and prozostrodontians) from

107 Brazil and Argentina in a fairly continuous span of $\sim 8$ million years (Abdala and Ribeiro, 2010;

108 Martinelli and Soares, 2016). Among prozostrodontians, many taxa are tiny with some having

109 basal skull lengths of only 20-40 mm (e.g. Minicynodon, Brasilodon, Brasilitherium) (Bonaparte

110 et al., 2010; Martinelli, Soares and Schwanke, 2016). Given that they are so small and delicate,

111 the best represented elements are jaws and teeth, with only a few partial and/or complete skulls

112 and very few associated postcranial bones.

113 Apart from numerous studies on the phylogenetic relationships of non-mammaliaform

114 cynodonts (as mentioned above), various studies have provided insight into the locomotory,

115 masticatory, reproductive, ventilatory and physiological capacities of this clade. Differentiation

116 of the vertebral column and an increasingly parasagittal gait during non-mammaliaform 
117 cynodont evolution resulted in improved agility and increased foraging capacity (Kemp, 2005;

118 Hopson, 2012) (Fig. 1(1)). The presence of a bony secondary palate (Fig. 1(2)), which although

119 not selected for endothermy (as it was more likely selected for bite strength as in dicynodont and

120 therocephalian therapsids; Thomason and Russell, 1986), would have allowed them to eat and

121 breathe simultaneously allowing more continuous ventilation to take place (Bennett and Ruben,

122 1986). Tooth differentiation and occlusion as well as reorganization of the jaw musculature

123 facilitated radiations into new ecological niches (e.g. bucco-lingually expanded postcanines in

124 the Gomphodontia (Fig. 1(3)); Crompton, 1955; Abdala and Ribeiro, 2010) allowing for

125 increased energy assimilation (Kemp, 2005). The recovery of a juvenile (BSL $40 \%$ that of

126 adults) with two adult specimens of the Middle Triassic trirachodontid Trirachodon within a

127 burrow (NMQR 3281; Groenewald, Welman and MacEachern, 2001) strongly suggests that

128 some form of extended parental care had begun to evolve within this lineage (Fig. 1(4)). The loss

129 of the pineal foramen within the Probainognathia (Fig. 1(5)) also suggests improved reproductive

130 timing, as well as improved thermoregulatory control (e.g., Benoit et al., 2016a). Modifications

131 to the neurosensory system occurred during the Triassic as well. For example, changes to the

132 maxillary nerves in non-mammaliaform probainognathians suggests that maxillary vibrissae (i.e.

133 whiskers) were present in some tritylodontids, the tritheledontid Pachygenelus and brasilodontid

134 Brasilitherium indicating that hair (perhaps not a pelage), a key mammalian feature (Fig. 1(6)),

135 had evolved by the early Late Triassic (Benoit, Manger and Rubidge, 2016b). An efficient

136 counter current exchange ventilation system for the conservation of heat and water evolved

137 within the more derived non-mammaliaform prozostrodontians as ossified maxilloturbinate

138 bones have been found in the nasal cavity of the derived Late Triassic-Early Jurassic

139 tritheledontid Elliotherium (Crompton et al., 2017). This system facilitates high ventilation rates 
140 in extant mammals and is a prerequisite for homeothermic endothermy (Crompton et al., 2017)

141 (Fig. 1(7?)). However, ossified maxilloturbinate bones have also been found in the Late Triassic-

142 Early Jurassic mammaliaform Morganucodon. Thus, this feature either evolved independently in

143 the two lineages during the Rhaetian or it did so prior to the divergence of Tritheledontidae and

144 Mammaliaformes during the Carnian, placing the emergence of this system earlier by some 13

145 million years (Fig. 1(7?)). The above examples show that there was a progressive increase in the

146 acquisition of anatomical and physiological mammalian features during the Middle-Late

147 Triassic. However, these studies are based on morphology and taphonomy and cannot provide

148 insight into the growth patterns within the non-mammaliaform cynodont lineage.

Life history data, such as growth patterns and growth rates and how these change through ontogeny, can be obtained from extinct vertebrates by studying their bone microstructure or osteohistology. Given the importance of non-mammaliaform cynodonts in understanding the

152 origin and evolution of mammalian growth patterns, numerous osteohistological studies have 153 been conducted, but these have mostly focused on basal taxa and the more derived Cynognathia

154 (e.g. Ricqlès, 1969; Botha and Chinsamy, 2000, 2004, 2005; Ray, Botha and Chinsamy, 2004;

155 Chinsamy and Abdala, 2008; Botha-Brink, Abdala and Chinsamy, 2012; Veiga, Botha-Brink and 156 Soares 2018; Butler, Abdala and Botha-Brink, in press). These studies indicate that fibrolamellar 157 bone (indicative of rapid bone deposition rates) is the dominant bone tissue type, at least during 158 early to middle ontogeny. This bone tissue type is plesiomorphic for non-mammaliaform 159 cynodonts, having been found in even the most basal members of the clade such as the small late 160 Permian Procynosuchus (Ray, Botha and Chinsamy, 2004). Early Triassic basal epicynodonts 161 remained small, but grew more rapidly than Procynosuchus (Botha and Chinsamy, 2004; Butler 162 et al., in press), possibly in response to shortened life expectancies in the post-extinction 
163 environment following the Permo-Triassic mass extinction (Botha-Brink et al., 2016). The

164 Middle Triassic Cynognathia generally show an increase in body size and rapid growth rates

165 during early and mid-ontogeny, although they took longer to reach skeletal maturity compared to

166 the Early Triassic taxa, as shown by the multiple Lines of Arrested Growth (LAG) prior to

167 growth asymptoty (Botha-Brink, Abdala and Chinsamy, 2012). LAGs (represented by a cement

168 line) and annuli (comprising narrow regions of slowly forming parallel-fibered or lamellar bone)

169 indicate temporary cessations or decreases in bone growth respectively, and based on

170 experiments on extant vertebrates, are known to be deposited annually during the cold or dry

171 season (e.g. Hutton, 1986). The transition to multi-year growth to reproductive and skeletal

172 maturity in the Cynognathia may be due to larger body sizes or a relaxation on the selection for

173 early developmental times when life expectancies were higher during the Middle Triassic

174 (Botha-Brink et al., 2016). Exceptions to this are the relatively smaller-bodied traversodontids

175 Andescynodon and Massetognathus that grew relatively more slowly (see Chinsamy and Abdala,

1762008 for a detailed review). All non-mammaliaform cynodonts exhibit slower forming bone

177 tissues, such as parallel-fibered or lamellar bone, upon departure from the juvenile stage (Botha-

178 Brink, Abdala and Chinsamy, 2012), with growth asymptoty being represented by an External

179 Fundamental System (EFS, Cormack, 1987; or outer circumferential lamellae by other authors,

180 e.g. Chinsamy-Turan, 2005). An EFS is a peripheral region of avascular or very poorly

181 vascularized slowly forming bone tissue that often contains multiple, closely spaced LAGs, and

182 indicates that skeletal growth has essentially ceased. Although it is rare to find senescent

183 individuals in the fossil record, the presence of this feature in at least some taxa indicates that,

184 similar to other vertebrates (Woodward et al., 2001; Lee et al., 2013), non-mammaliaform

185 cynodonts underwent determinate growth. 
Although much research has been conducted on the osteohistology of basal non-

187 mammaliaform cynodonts and the more derived Cynognathia, relatively little attention has been

188 given to the Probainognathia (Ricqlès, 1969; Ray, Botha and Chinsamy, 2004; Botha-Brink,

189 Abdala and Chinsamy, 2012). Apart from the tritylodontid Tritylodon (Botha-Brink, Abdala and

190 Chinsamy, 2012), only brief descriptions of poorly preserved material have been provided for

191 Chiniquodon, Bienotherium (Ricqlès, 1969) and Trucidocynodon (Botha-Brink, Abdala and

192 Chinsamy, 2012). These taxa represent either the early (Trucidocynodon, Chiniquodon from the

193 Carnian) or later part of non-mammaliaform probainognathian evolution (Bienotherium from the 194 Rhaetian-Hettangian, Oligokyphus from the Rhaetian-Pliensbachian) (Fig. 1). We describe here

195 the limb bone osteohistology of four non-mammaliaform prozostrodontian probainognathian

196 taxa from the Carnian and Norian of Brazil. We assess their life histories using limb bone

197 osteohistology and compare their growth patterns with those of other non-mammaliaform

198 cynodonts (e.g., basal cynodonts, cynognathians, basal probainognathians) and

199 Mammaliaformes, thus filling a knowledge gap in the cynodont-mammal transition.

200

201

MATERIAL AND METHODS

202

Institutional Abbreviations

203

NMQR, National Museum, Bloemfontein; UFRGS-PV-T-, Universidade Federal do Rio Grande do Sul, Brazil, Paleovertebrates Collection, Triassic.

\section{Material}

207 Our sample comprises Prozostrodon brasiliensis (estimated BSL $75-80 \mathrm{~mm}$ ), which is one of 208 the most basal prozostrodontians (Bonaparte and Barberena, 2001; Liu and Olsen, 2010; 
209 Martinelli, Soares and Schwanke, 2016), the tritheledontid Irajatherium hernandezi (Martinelli

210 et al., 2005; Oliveira, Martinelli and Bento Soares, 2011) (estimated maximum BSL 80 mm), and

211 the brasilodontids Brasilodon quadrangularis and Brasilitherium riograndensis (both with a

212 maximum estimated BSL of $40 \mathrm{~mm}$ ). The BSLs of Brasilodon and Brasilitherium are taken from

213 specimens that were assigned to each of these taxa by Bonaparte (2013), Bonaparte, Martinelli

214 and Schultz (2005) and Bonaparte, Soares and Martinelli (2012). However, Liu and Olsen (2010)

215 and Martinelli and Bonaparte (2011) suggested that these two taxa should be synonymised and

216 that the specimens of both taxa represent different ontogenetic stages of one taxon (see also

217 Martinelli, 2017). With the exception of one specimen (UFRGS-PV 1043; Bonaparte et al.,

218 2010; Bonaparte, Soares and Martinelli, 2012, used also in other contributions), most specimens

219 referred to Brasilitherium are small-sized compared to the Brasilodon ones. Some authors have

220 maintained the use of both taxa in their analyses (e.g., Bonaparte, 2013; Soares, Martinelli and

221 Oliveira, 2014; Martinelli et al., 2017a, b), but studies are currently being undertaken (AGM,

222 MBS) that will shed light on this issue. A consensus has yet to be reached and thus, the taxa are

223 treated separately here, with the caveat that the osteohistology of these two taxa may be shown to

224 represent one species in the future.

The material of Prozostrodon brasiliensis includes a proximal portion of a left humerus

226

227

228

229

230

231

and complete left femur of the holotype UFRGS-PV-248-T (the only known specimen with

postcranial material). UFRGS-PV-248-T was found 200 m northwest of the Cerriquito Hill, in a road cut on highway BR-287, in the municipality of Santa Maria, Rio Grande do Sul State, Brazil (Bonaparte and Barberena, 2001). It comes from the Hyperodapedon Assemblage Zone (AZ) of the Candelária Sequence (Horn et al., 2014), Santa Maria Supersequence (Zerfass et al., 2003), which is considered to be Late Carnian in age based on biostratigraphical correlations 
232 with the Ischigualasto Formation of Argentina (e.g., Langer, 2005) and radiometric dating using

$233 \mathrm{U}-\mathrm{Pb}$ zircon geochronology (233.23 \pm 0.73 million years ago; Langer, Ramezani and Da Rosa, 234 2018).

235 The material of Irajatherium hernandezi comprises an almost complete humerus (with 236 only the proximal end missing) (UFRGS-PV-1072-T), which was described by Oliveira,

237 Martinelli and Soares (2011). The material of Brasilodon quadrangularis consists of the shaft of 238 an ulna (the articular proximal portion was preserved separately) associated with a skull and jaws 239 (UFRGS-PV-765-T). It was figured in Bonaparte, Martinelli and Schultz (2005:fig. 6). The 240 Brasilitherium riograndensis material consists of two specimens: UFRGS-PV-1308-T (small241 sized specimen), preserved in a sandstone block with a radius, ulna, femur, tibia, and fibula 242 (associated with a lower jaw and maxilla referred to Brasilitherium, which has not been formally 243 published); UFRGS-PV-1043-T (large-sized specimen), a proximal portion of the left femur, 244 which is associated with a skull, jaws and other postcranial elements (e.g., Bonaparte et al., 245 2010; Bonaparte, Soares and Martinelli, 2012; Rodrigues, Ruf and Schultz, 2013, 2014; Ruf et 246 al., 2014).

All the specimens of Irajatherium, Brasilitherium and Brasilodon come from the outcrop known as Linha São Luiz Site, located approximately 3 km north of Faxinal do Soturno city, Rio

249 Grande do Sul State, Brazil. They come from the Riograndia AZ (above the Hyperodapedon 250 AZ) of the Candelária Sequence (Horn et al., 2014), Santa Maria Supersequence (Zerfass et al., 2003), of Norian age based on a radiometric U-Pb date of the Linha São Luiz Site (maximum of 225.42 \pm 0.25 million years ago; Langer, Ramezani and Da Rosa, 2018) and biostratigraphical correlation with the Ischigualasto and Los Colorados formations of Argentina (e.g., Martínez et 254 al., 2013). 


\section{Methods}

257 All the elements were measured and photographed prior to thin sectioning. Although mostly

258 fragmentary material was thin sectioned (given the rarity of the taxa), all the bones were

associated with diagnostic cranial material. The elements were serially sectioned where possible, but some of the bones were so small that only one or two sections could be recovered from each bone. The thin sectioning process was conducted at the National Museum, Bloemfontein, South Africa. The bones were embedded in the clear Struers Epofix epoxy resin under vacuum. Once set, the resin blocks were serially sectioned using a Struers Accutom-100 cutting and grinding machine. Each thick section was adhered to a frosted glass slide using the Struers Epofix resin. These sections were then ground to a thickness of approximately $60 \mu \mathrm{m}$ using the Struers Accutom-100 and polished manually using Struers Accutom-100 cutting oil. The resulting thin sections were then digitally rendered under ordinary, polarized (PL), and cross-polarized light (CPL), using a Nikon Eclipse Ci POL polarizing microscope and DS-Fi3 digital camera in NISElements 4.6 (Nikon Corp.). Osteohistology terminology follows that of Francillon-Vieillot et al.

270 (1990) and Ricqlès et al. (1991).

\section{RESULTS}

Prozostrodon brasiliensis

274 A left humerus (UFRGS-PV248a-T) comprising the proximal midshaft (the region of the 275 deltopectoral crest) and epiphysis was thin sectioned (Fig. 2A-C). In transverse section, the bone contains a relatively small medullary cavity surrounded by a thick compact cortex (Fig. 2A). A

277 few thick bony trabeculae traverse the otherwise clear medullary cavity. Several large resorption 
278 cavities in the perimedullary region are surrounded by thick layers of endosteal lamellae. A few

279 of these resorption cavities extend into the area of the deltopectoral crest (Fig. 2A). Small

280 secondary osteons, demarcated by their cement lines, are rare and limited to the innermost cortex

281 in the midshaft, but are more abundant in the metaphyseal region. The compact cortex is

282 comprised of a woven-fibered matrix with abundant, large, globular, haphazardly arranged

283 osteocyte lacunae and numerous vascular canals (Fig. 2B, C) forming a fibrolamellar bone tissue

284 complex (defined by the presence of a woven-fibered bone matrix associated with primary

285 osteons; Francillon-Vieillot et al., 1990). Most of the canals form poorly developed

286 longitudinally-oriented primary osteons in radial rows, but some radiate transversely, particularly

287 in the region of the deltopectoral crest (Fig. 2A), and others a reticular pattern, especially at the

288 bone periphery, further down the midshaft. The fibrolamellar bone is interrupted by two regions

289 of slower forming parallel-fibered bone tissue (Fig. 2B). The first is a thick region (16 $\mu \mathrm{m})$ of

290 less vascularized parallel-fibered bone tissue midway through the cortex. The osteocyte lacunae

291 are more uniformly distributed in this region (i.e. there is no evidence of static osteogenesis;

292 Stein and Prondvai, 2013). The parallel-fibered bone matrix becomes increasingly organized

293 within its center to form slowly forming lamellar bone with flattened osteocyte lacunae arranged

294 parallel to one another. A LAG (Fig. 2A, B), which becomes an annulus in parts (Fig. 2C),

295 indicating a temporary cessation or decrease in growth rate respectively, traverses the middle of

296 this slower growing region. A thin zone of more vascularized fibrolamellar bone follows from

297 this region, which is then followed by a second, thinner region $(7 \mu \mathrm{m})$ of parallel-fibered bone in

298 the outer cortex. The bone tissue returns to highly vascularized fibrolamellar bone at the

299 subperiosteal surface with a reticular or radiating vascular network (Fig. 2B), showing that the

300 bone was still actively growing at the time of death. Sharpey's fibers, indicating areas of muscle 
301 attachment, were observed in the proximal metaphysis on the dorsal side of the bone (Fig. 2C),

302 possibly for the insertion of the latissimus dorsi or teres minor muscles (Jenkins, 1971). In transverse section, the left femur (UFRGS-PV-248b-T) comprises a small medullary

304

305 cavity surrounded by a thick compact cortex (Fig. 2D). The medullary cavity is completely clear and is only traversed by a few thick broken trabeculae further away from the midshaft. Several large resorption cavities can be found in the perimedullary region (Fig. 2D). Secondary osteons are small and rare, and limited to the innermost cortex, similar to the humerus. The compact cortex is similar to the humerus, i.e. it comprises highly vascularized fibrolamellar bone with mostly short radiating vascular canals and longitudinally-oriented primary osteons in the inner cortex and short radiating canals at the subperiosteal surface (Fig. 2D), which become more reticular further down the midshaft (Fig. 2E, F). The fibrolamellar bone is also interrupted by parallel-fibered bone tissue (10 $\mu \mathrm{m}$ thick) midway through the cortex, similar to the humerus. It appears as two regions in some areas (similar to the humerus), but merges to form one zone in others. A LAG (Fig. 2D), which becomes an annulus in parts (Fig. 2E, F), can be seen running through parts of this region. Rapid growth resumes after this slow growing region in the form of rapidly growing fibrolamellar bone, indicating active growth at the time of death. Sharpey's fibers, indicating areas of muscle insertion, were observed on the dorsomedial and ventrolateral sides of the midshaft, possibly for the origin of the femoro-tibialis and adductor muscles, respectively, as well as on the ventral side of the proximal epiphysis (Fig. 2G), possibly for the insertion of the ilio-femoralis or adductor muscles (Jenkins, 1971). The femoral longitudinal sections reveal a similar bone tissue pattern to the transverse sections. The vascular canals in both proximal and distal epiphyses stop just beneath the bone surfaces, which are themselves capped by a thin layer of calcified cartilage. 


\section{Irajatherium hernandezi}

326 The midshaft and distal end of a left humerus (UFRGS-PV-1072-T) was available for thin

327 sectioning (Fig. 3A-D). The bone tissues are not particularly well preserved and appear to have

328 been infiltrated with some kind of mineral. However, although parts appear to be diagenetic, the

329 main features of the bone tissue can be clearly observed from several well preserved patches of

330 primary bone. In transverse section, the bone comprises a small medullary cavity traversed by a

331 few thick trabeculae (Fig. 3A). Secondary remodeling is limited to a few small secondary

332 osteons in the inner cortex. The surrounding thick, compact cortex consists of an inner cortex of

333 fibrolamellar bone with mostly longitudinally-oriented primary osteons (in radiating rows in a

334 few patches) and a few short radiating canals (Fig. 3B, C). The outer third of the cortex gives

335 way to parallel-fibered bone and in places lamellar bone (Fig. 3A, B), with more uniformly

336 distributed osteocyte lacunae. At least one LAG (Fig. 3A) is present in this thick region, but

337 there appears to be more (Fig. 3B, D). Confirmation is difficult, however, as the diagenesis

338 appears to have highlighted the individual lamellae of the bone tissue. This would then suggest

339 the presence of lamellar bone, where the individual layers of this bone tissue type have been

340 highlighted by the mineral infiltration, and indicates slow bone deposition. The osteocyte lacuna

341 density is lower and their distribution more uniform in this region (Fig. 3D) compared to that

342 seen in the inner and mid-cortex (Fig. 3C). The distal longitudinal sections revealed similar bone

343 tissue patterns to the midshaft, but there are clearer views of numerous, large, globular osteocyte

344 lacunae in the metaphysis, possibly as a result of ongoing bone activity during remodeling in this 345 area. 
347 to slower growth. The slow growing zone may indicate an External Fundamental System (EFS),

348 but the presence of vascular canals within the slower growing region, as well as at the

349 subperiosteal suggests that the bone was still growing (although more slowly) and that maximum

350 size had yet to be reached. Although not fully grown, however, this individual was no longer a

351 juvenile as the overall growth rate had decreased indicating that it was a subadult that had

352 reached the growth deceleration phase.

353

354

\section{Brasilodon quadrangularis}

The ulna of Brasilodon (UFRGS-PV-765-T) contains a large clear medullary cavity surrounded

by a thin compact cortex (Fig. 4A). A thin layer of endosteal bone with flattened, parallel consists primarily of woven-fibered bone with large, globular, haphazardly arranged osteocyte lacunae and a few poorly developed tiny primary osteons (Fig. 4B, C), with a small patch of side of the bone there is a peripheral region that contains a few flattened osteocyte lacunae and differs in color from the rest of the cortex under cross polarized light. This region of lamellar bone may represent an annulus (Fig. 4D). A few tiny secondary osteons could be observed within the olecranon process (Fig. 4A).

\section{Brasilitherium riograndensis}

367 The radius, ulna, femur, tibia and fibula of the smaller individual of Brasilitherium were thin sectioned (UFRGS-PV-1308-T). The radius (UFRGS-PV-1308a-T) contains a large clear 
369 medullary cavity surrounded by poorly vascularized parallel-fibered bone (Fig. 5A). The

370 osteocyte lacunae are globular, but arranged uniformly throughout the cortex. The vascular

371 canals are all tiny and simple. Neither primary nor secondary osteons are present. There is no

372 change in tissue type towards the subperiosteal surface and growth marks are absent.

cortex. The bone tissues are simple, similar to the radius, but the flattened, parallel osteocyte lacunae indicate the presence of lamellar bone instead of parallel-fibered bone. In some patches, the individual lamellae can be clearly seen. Vascularization is simple, similar to the radius, although slightly more vascularized. One lamella, towards the subperiosteal surface, appears to be more prominent than the others, and is different in color under cross-polarized light compared to the other lamellae (Fig. 5B). It may represent a LAG, but this cannot be confirmed as it only appears in one corner of the bone. medullary cavity and thin cortex (Fig. 5C). A few broken bony trabeculae were observed in the center of the cavity. The bone tissue contains a mixture of types, ranging from woven-fibered to parallel-fibered to lamellar in various regions (Fig. 5C, D). Some tiny patches contain globular, haphazardly arranged osteocyte lacunae and a few tiny, poorly developed primary osteons, indicating fibrolamellar bone. Other areas contain more organized osteocyte lacunae some of which are flattened, indicating parallel-fibered and lamellar bone. In these regions, the vascular canals are simple. Although, not highly vascularized, the canals are more abundant than the radius and ulna. There is no evidence of a decrease in vascularization at the subperiosteal surface, indicating continued growth. A few tiny secondary osteons were observed in the 391 innermost cortex. Growth marks were not observed. 
cavity and a mixture of bone tissue types in the compact cortex (Fig. 5E). Patches of woven-

fibered bone with a few primary osteons (Fig. 5F) indicating the presence of poorly developed

fibrolamellar bone, is mixed with areas of parallel-fibered bone. One tiny secondary osteon was observed in the outer cortex. Growth marks are absent.

There is a patch of globular osteocyte lacunae towards the end of the bone in the region of the metaphysis. A few small vascular canals are also present in this region. The osteocyte lacunae comprise a mixture of both globular and flattened bodies. Growth marks were not observed.

cavity was observed towards the direction of the greater trochanter, otherwise secondary patches of woven-fibered bone with haphazardly arranged osteocyte lacunae in the inner cortex, but they become increasingly uniformly distributed towards the subperiosteal surface to form parallel-fibered bone and even lamellar bone in places (Fig. 5I). Vascularization is moderate and comprises some small longitudinally-oriented primary osteons and simple canals. A LAG runs through the mid-cortex on the posterior side of the bone, although it should be noted that it cannot be traced around the whole bone. There is no evidence of an EFS, but the increased prevalence of parallel-fibered bone at the subperiosteal surface suggests an overall decrease in growth rate and a departure from the juvenile stage. Although not fully grown, this individual was likely a subadult when it died. 


\section{DISCUSSION}

417 Prozostrodon brasiliensis represents one of the most basal members of the Prozostrodontia (Liu 418 and Olsen, 2010; Martinelli et al., 2017a, b) and provides a good example of the growth patterns 419 that existed during the early evolution of this clade. The presence of well vascularized, rapidly 420 forming fibrolamellar bone is similar to that found in all other non-mammaliaform cynodonts, 421 including one of the most basal members, Procynosuchus, which exhibits fibrolamellar bone 422 during the early stages of ontogeny (Botha-Brink, Abdala and Chinsamy, 2012). The temporary 423 decrease and cessation in growth shows that Prozostrodon grew cyclically as did most of the 424 gomphodont cynodonts (Botha-Brink, Abdala and Chinsamy, 2012). This pattern differs from 425 that observed in the basal probainognathians Chiniquodon (Ricqlès, 1969) and Trucidocynodon 426 (Botha-Brink, Abdala and Chinsamy, 2012), which exhibit sustained growth. However, it should 427 be noted that the elements examined by previous authors do not represent mature individuals 428 (Botha-Brink, Abdala and Chinsamy, 2012; JBB pers. obs. 2015), casting doubt as to whether 429 these taxa underwent sustained growth to skeletal maturity. More material is required to 430 adequately deduce the growth patterns of these two taxa.

Prozostrodon, compares well with the Early Jurassic tritylodontid Tritylodon longaevus (BothaBrink, Abdala and Chinsamy, 2012), although the reticular patches are also similar to the Early

434 Triassic basal epicynodont Thrinaxodon liorhinus (Botha-Brink, Abdala and Chinsamy, 2012).

435 Vascularization is higher than that observed in Chiniquodon, which contains fewer

436 longitudinally-oriented primary osteons (JBB pers. obs. 2015), but less vascularized than

437 Trucidocynodon, which exhibits a plexiform vascular arrangement (Botha-Brink, Abdala and 
438 Chinsamy, 2012). The higher vascularization in Trucidocynodon may be related to its larger

439 body size (BSL $188 \mathrm{~mm}$, Oliveira, Soares and Schultz, 2016) as within a given clade larger

440 bodied taxa tend to grow more quickly than their smaller relatives (Case, 1978).

441 It is clear from the highly vascularized, rapidly deposited bone tissues that Prozostrodon

442 grew quickly during the favorable growing season. The expansive width of the slow growing

443 parallel-fibered zone is noteworthy, however, as this differs from the gomphodonts that have

444 been studied to date (i.e. Diademodon, Trirachodon, Langbergia, Andescynodon, Traversodon,

445 Gomphodontosuchus, Protuberum, Scalenodontoides, Exaeretodon; Botha and Chinsamy, 2000,

446 2004; Chinsamy and Abdala, 2008; Botha-Brink, Abdala and Chinsamy, 2012; Veiga, Botha-

447 Brink and Soares, 2018), all of which express LAGs or narrow annuli of parallel-fibered or

448 lamellar bone. The broadness of this slow growing zone indicates that either the animal was able

449 to continue growing through much of the cold or dry season, only ceasing when the LAG was

450 deposited, or that it experienced a particularly long and harsh unfavorable growing season and

451 thus, grew slowly for longer under these conditions.

Although UFRGS-PV-248-T is the largest known specimen of Prozostrodon, the

453 presence of continued, active rapid growth at the periphery of the bones indicates that it was not

454 a mature individual. There is no overall deceleration in growth and thus, it had not likely attained

455 reproductive maturity before it died. A deceleration in growth rate typically accompanies the

456 onset of reproductive maturity in extant mammals that take several years to reach a large body

457 size (Owens, Dubeski and Hanson, 1993; Köhler et al., 2012), but may occur after asymptotic

458 size is reached in fast growing, very small mammals (e.g. the long-clawed shrew, Nesterenko

459 and Ohdachi, 2001; grey mouse lemur, Castanet et al., 2004) or prior to this transition in very

460 large taxa (e.g. elephant, Lee and Werning, 2008). Although the maximum known BSL of 
461 Prozostrodon, which is $80 \mathrm{~mm}$, does not represent a fully grown individual, the taxon is not

462 likely to have reached the large body sizes of extant mammals that take several years to reach

463 reproductive maturity, such as ruminants (two to four years), the hippopotamus (10 years) or

464 elephant (15 years) (Miller and Zammuto, 1983; Promislow and Harvey, 1990; Köhler et al.,

465 2012). Prozostrodon falls within the size range of small extant mammals that typically attain

466 reproductive maturity within one year (Miller and Zammuto, 1983; Promislow and Harvey,

467 1990). However, given the mid-cortical growth mark in the Prozostrodon material and continued

468 rapid growth, it is likely that this taxon took longer than one year to become reproductively

469 mature.

470

To date, Irajatherium hernandezi is the only tritheledontid cynodont for which the limb

471 bones have been studied histologically. The bone tissues revealed rapidly forming fibrolamellar

472 bone with similar vascular arrangements to that seen in Tritylodon (Botha-Brink, Abdala and

473 Chinsamy, 2012). Although the material is poorly preserved, peripheral interruptions in growth

474 (at least one LAG) can be clearly seen. The presence of vascular canals at the subperiosteal

475 surface indicates that growth continued, but the canals are fewer and smaller compared to those

476 in the mid and inner cortex and a slower forming tissue (lamellar bone) appears in this region,

477 indicating a decrease in growth rate. The presence of at least one LAG, however, indicates that

478 growth was cyclical. Botha-Brink, Abdala and Chinsamy (2012) suggested that Tritylodon

479 generally grew in a sustained manner as growth marks were rarely found in the material studied,

480 but the presence of a double LAG in a radius and fibula belonging to specimen $\mathrm{BP} / 1 / 5167$

481 indicates that Tritylodon was capable of cyclical growth. Upon further investigation it was found

482 that much of the Tritylodon material that has been thin sectioned represents juveniles and the

483 presence of continued growth after the LAG in the bones of BP/1/5167 indicates that it was just 
484 over a year old at the time of death and not fully grown (JBB pers. obs. 2018). Furthermore, a

485 mid-cortical LAG is present in the tritylodontid Bienotherium femur described by Ricqlès

486 (1969), which presents continued growth following this growth mark and then a wide region of

487 very poorly vascularized lamellar bone tissue that may represent an EFS (JBB pers. obs. 2015).

488 This suggests that tritylodontids underwent cyclical growth during mid-ontogeny.

489 In contrast, the Irajatherium material reveals that a slower growth phase had been

490

491

492

493

494

495

496

497

498

499

500

501

502

503

504

505

506

reached and was thus not likely to have grown significantly larger than the maximum known

BSL of $80 \mathrm{~mm}$. This suggests that it was a smaller taxon than Tritylodon (maximum known BSL

$140 \mathrm{~mm}$ and an estimated body mass of $10 \mathrm{~kg}$; Gaetano, Abdala and Govender, 2017) or

Prozostrodon. Despite the smaller body size, however, the bone tissues of Irajatherium exhibit rapid growth rates, similar to the larger Tritylodon.

Among the small-sized prozostrodontians from South America, Irajatherium is the only one in which fossorial features in the humerus have been recognized (Martinelli et al., 2005).

This taxon has a stout humerus, with twisted and broad proximal and distal epiphyses, a

proximally deep bicipital groove, and two well-developed processes for the teres major muscle (Martinelli et al., 2005; Oliveira, Martinelli and Soares, 2011). The osteohistology revealed a relatively thick cortex where the compact bone wall (cortical thickness) comprises $29 \%$ of the bone diameter. Similarly thick cortices have been found in extant burrowing mammals such as Bathyergus suillus (Montoya-Sanhueza and Chinsamy, 2016) Heterocephalus glaber (naked mole rat, 31\%) and Erethizon (New World porcupine $>30 \%$ ), as well as the burrowing or digging lizards Gerrhonotus grantis, Heloderma suspectum and Phrynosoma douglassi (Magwene, 1993; Botha and Chinsamy, 2004). A thick, robust humerus would have aided in counteracting strong bending forces during forelimb digging. Prozostrodon also has relatively thick cortices (humerus 
$50730 \%$, femur 35\%), but no fossorial adaptations can be identified in the limb bones of this taxon.

508 The thick cortices may be attributed to a larger body size compared to Irajatherium or as yet

509 unidentified biomechanical adaptations.

510 The bone tissues of Brasilodon and Brasilitherium are similar, with a mixture of woven

511 and parallel-fibered bone tissues. If we place all of our brasilodontid study material in an

512 ontogenetic series: the Brasilitherium UFRGS-PV-1308-T individual is the smallest, with

513 Brasilodon UFRGS-PV-765-T being larger and Brasilitherium UFRGS-PV-1043-T the largest

514 individual in the series. This is supported by the osteohistology analysis. The bones of the

515 smallest Brasilitherium UFRGS-PV-1308-T contain a mixture of rapidly forming woven-fibered

516 bone and slower growing parallel-fibered bone. The absence of any growth marks or an EFS

517 suggests that this individual was in an early ontogenetic stage (within its first year) at the time of

518 death. The bone tissues of Brasilodon UFRGS-PV-765-T also contain a mixture of woven-

519 fibered bone and parallel-fibered bone, but there appears to be an annulus at the bone periphery,

520 suggesting that it was ontogenetically older (it had reached its first year) than the small

521 Brasilitherium UFRGS-PV-1308-T. The larger Brasilitherium UFRGS-PV-1043-T contains a

522 LAG with continued growth after this growth mark, suggesting that it was ontogenetically older

523 than the Brasilodon individual. It is recognized that our sample size is very small and more

524 material is required for osteohistology to be used as supportive evidence for the synonymy of

525 these two taxa. However, it is worth noting that there is no evidence in the study material to

526 contradict the possibility that Brasilodon and Brasilitherium are synonymous and that they may

527 represent different ontogenetic stages in a series (see also Liu and Olsen, 2010; Martinelli and

528 Bonaparte, 2011; Martinelli, 2017). 
PV-1043-T), prior to the onset of the slower forming peripheral parallel-fibered bone, suggests

531 that this taxon took longer than one year to reach somatic or reproductive maturity. Thus,

532 although it was a tiny species and capable of growing quickly (given the presence of rapidly

533 forming woven-fibered bone), it still took longer than one year to reach asymptotic size. This

534 contrasts to what is seen in similar-sized extant mammals (e.g. rodents; Nesterenko and Ohdachi, 535 2001).

536 Comparing the brasilodontids with mammaliaforms is difficult because the only non-

537 mammalian mammaliaform that has been sectioned is the tiny (BSL $30 \mathrm{~mm}$, Kemp, 2005)

538 Morganucodon watsoni (Chinsamy and Hurum, 2006) and the sections are poorly preserved.

539 Chinsamy and Hurum (2006) identified a patch of woven-fibered bone and noted some

540 peripheral parallel-fibered bone tissue with LAGs in their Morganucodon sample, but much of

541 the material is diagenetic. There is another section of a Morganucodon ulna in the Muséum

542 national d'Histoire naturelle (Paris, France), but it is also badly preserved and little information

543 can be obtained from the sample (JBB pers. obs. 2015). Given that Chinsamy and Hurum (2006)

544 noted a mixture of woven-fibered and parallel-fibred bone, it appears that it grew in a similar

545 manner to the brasilodontids. However, O’Meara and Asher (2016) proposed that

546 Morganucodon grew more similarly to extant placental mammals than did more basal non-

547 mammaliaform cynodonts because it exhibits a truncated growth period, with rapid juvenile

548 growth and a very short period of adult growth. The narrow range of skull lengths in

549 Morganucodon supports their proposal where rapid attainment of somatic maturity would restrict

550 size variation (O’Meara and Asher, 2016). The skull length variation of Brasilodon and

551 Brasilitherium (BSL ranging from 20-40 mm) exceeds that of the known samples of 
552 Morganucodon (Luo, Crompton and Sun, 2001; O'Meara and Asher, 2016). Combined with the

553 osteohistology results, it suggests that these Brazilian non-mammaliaform prozostrodontians had

554 a more protracted growth period where, although juvenile growth was rapid, they still took

555 longer to reach skeletal maturity than did Morganucodon.

556 Brasilodon and Brasilitherium grew more quickly than the similar-sized Late Cretaceous

557 eutherian mammals Barunlestes butleri (BSL approximately $30 \mathrm{~mm}$, Kielan-Jaworowska, Cifelli

558 and Luo, 2004) and Zalambdalestes lechei (BSL approximately $50 \mathrm{~mm}$, Kielan-Jaworoswka,

559 Cifelli and Luo, 2004). Contrary to the brasilodontids, the bones of these eutherians are

560 composed entirely of very poorly vascularized lamellar-zonal bone, indicative of slow growth

561 (Chinsamy and Hurum, 2006). Given that all these taxa were similar in body size, the differences

562 in growth cannot be attributed to differences in size. Instead, the brasilodontids exhibit similar

563 bone tissues and growth patterns to the Late Cretaceous multituberculates Kryptobaatar

564 dashzevegi (BSL approximately $30 \mathrm{~mm}$, Kielan-Jaworowska, 1970) and Nemegtbaatar gobiensis

565 (BSL approximately $45 \mathrm{~mm}$, Kielan-Jaworowska, 1974). Chinsamy and Hurum (2006) found

566 woven-fibered bone in a Kryptobaatar femur from what appears to be from a juvenile individual

567 (absence of decreased growth rate), indicating rapid growth. The femur of Nemegtbaatar

568 contains parallel-fibered bone and a LAG, indicating slightly slower cyclical growth. Both bone

569 tissue types and growth marks were observed in the brasilodontids, suggesting a closer similarity

570 in growth pattern to the multituberculates than to the eutherian mammals Barunlestes and

571 Zalambdalestes. Sampling more early eutherians and other Mesozoic mammal lineages,

572 however, will provide a more conclusive assessment of the growth patterns of stem and early

573 crown mammals. 
Although comprehensive studies on extant monotreme and marsupial mammal

575

576

577

578

579

580

581

582

583

584

585

586

587

588

589

590

591

592

593

594

595

596

osteohistology are lacking, brief descriptions of isolated elements show that the extant

monotremes Tachyglossus aculeatus (echidna) and Ornithorhynchus anatinus (platypus), as well

as the marsupials Didelphis virginiana (North American opossum) and Macropus (kangaroo)

(Chinsamy-Turan and Hurum, 2012) exhibit LAGs during mid-ontogeny showing that they

exhibit a protracted growth period during this stage. However, these taxa are all much larger than the brasilodontids, making direct comparisons difficult and the osteohistology of marsupials of equivalent size (e.g. marsupial mice) have yet to be described. Extant placental mammals of a similar body size to the brasilodontids typically take less than one year (just a few weeks or months depending on the species) to reach reproductive maturity. Despite the brasilodontids being similar in size to small extant placental mammals that typically reach reproductive maturity within one year (Miller and Zammuto, 1983; Promislow and Harvey, 1990), these animals still took more than one year to reach growth attenuation. The relatively more protracted growth period of the brasilodontids suggests that they had yet to attain the truncated growth period postulated for Morganucodon (Fig. 1(6)), which is typical of extant placental mammals of similar body size (O’Meara and Asher, 2016).

\section{CONCLUSIONS}

The osteohistological assessment of several non-mammaliaform prozostrodontian cynodont taxa from basal to more derived forms indicates the presence of high growth rates, similar to other non-mammaliaform cynodonts. Rapid early growth with annual interruptions later in ontogeny is clearly observed in Prozostrodon, the most basal prozostrodontian, and in the tritheledontid Irajatherium. Brasilodon and Brasilitherium, which are currently considered to be the sister taxa 
597 to Mammaliaformes, grew more slowly than the less derived cynodonts and more similarly to the 598 mammaliaform Morganucodon and the multituberculates Kryptobaatar and Nemegtbaatar. The 599 slower growth rates in these brasilodontids compared to other non-mammaliaform cynodonts 600 may be related to phylogeny and/or decreased body sizes as all these taxa were very small. When 601 compared with similar-sized extant mammals, they may have grown more slowly to adult size as 602 their osteohistology shows it took more than one year for growth to attenuate, thus taking more 603 than one year for these animals to reach skeletal maturity. Thus, although the Prozostrodontia 604 exhibit increasingly mammalian characteristics, including rapid juvenile growth, the small 605 derived, brasilodontid non-mammaliaform prozostrodontians still exhibit an extended growth 606 period compared to similar-sized extant mammals.

607

608

\section{REFERENCES}

609

610

611

612

613

614

615

616

617

618

619

Abdala F. 2007. Redescription of Platycraniellus elegans (Therapsida, Cynodontia) from the Lower Triassic of South Africa, and the cladistic relationships of eutheriodonts. Palaeontology 50:591-618.

Abdala F, Ribeiro AM. 2010. Distribution and diversity patterns of Triassic cynodonts (Therapsida, Cynodontia) in Gondwana. Palaeogeography, Palaeoclimatology, Palaeoecology 286:202-217.

Bennett AF, Ruben JA. 1986. The metabolic and thermoregulatory status of therapsids. In: Hotton III N, MacLean PD, Roth JJ, Roth EC, eds. The ecology and biology of mammal-like reptiles. Washington DC: Smithsonian Institution Press, 207-218.

Benoit J, Abdala F, Manger PR, Rubidge BS. 2016a. The sixth sense in mammalians forerunners: Variability of the parietal foramen and the evolution of the pineal eye in South 
620

621

622

623

624

625

626

627

628

629

630

631

632

633

634

635

636

637

638

639

640

641

642

African Permo-Triassic eutheriodont therapsids. Acta Palaeontologica Polonica 61:777789.

Benoit J, Manger PR, Rubidge BS. 2016b. Palaeoneurological clues to the evolution of defining mammalian soft tissue traits. Scientific Reports 6:25604.

Bonaparte JF. 2013. Evolution of the Brasilodontidae (Cynodontia-Eucynodontia). Historical Biology 25:643-653.

Bonaparte JF, Barberena MC. 2001. On two advanced carnivorous cynodonts from the Late Triassic of Southern Brazil. Bulletin of the Museum of Comparative Zoology at Harvard $156: 59-80$.

Bonaparte JF, Martinelli AG, Schultz CL, Rubert R. 2003. The sister group of mammals: small cynodonts from the Late Triassic of southern Brazil. Revista Brasileira Paleontologia 5:527.

Bonaparte JF, Martinelli AG, Schultz CL. 2005. New information on Brasilodon and Brasilitherium (Cynodontia, Probainognathia) from the Late Triassic of southern Brazil. Revista Brasileira Paleontologia 8:25-46.

Bonaparte JF, Schultz CL, Soares MB, Martinelli AG. 2010. La fauna local de Faxinal do Soturno, Triásico Tardío de Rio Grande do Sul, Brasil. Revista Brasileira de Paleontologia $13: 233-246$.

Bonaparte JF, Soares M, Martinelli AG. 2012. Discoveries in the Late Triassic of Brazil improve knowledge on the origin of mammals. Historia Natural, Fundación Felix de Azara, Tercera Serie 2012:5-30.

Botha J, Chinsamy A. 2000. Growth patterns deduced from the histology of the cynodonts Diademodon and Cynognathus. Journal of Vertebrate Paleontology 20:705-711. 
643 Botha J, Chinsamy A. 2004. Growth and life habits of the Triassic cynodont Trirachodon, 644 inferred from bone histology. Acta Paleontologica Polonica 49:619-627.

645 Botha J, Chinsamy A. 2005. Growth patterns of Thrinaxodon, a non-mammalian cynodont from 646 the Early Triassic of South Africa. Palaeontology 48:385-394.

647 Botha J, Abdala F, Smith R. 2007. The oldest cynodont: new clues on the origin and 648 diversification of Cynodontia. Zoological Journal of the Linnean Society 149:477-492.

649 Botha-Brink J, Abdala F, Chinsamy A. 2012. The radiation and osteohistology of non650 mammaliaform cynodonts. In: Chinsamy-Turan A, ed. Forerunners of mammals: radiation, 651 histology, biology. Bloomington: Indiana University Press, 223-246.

652 Botha-Brink J, Huttenlocker A, Angielczyk KD, Codron D, Ruta M. 2016. Breeding young as a 653 survival strategy during Earth's greatest mass extinction. Scientific Reports 6: 24053. DOI: $654 \quad 10.1038 /$ srep24053.

655 Butler E, Abdala F, Botha-Brink J. in press. Postcranial anatomy of the Early Triassic non656 mammaliaform cynodont Galesaurus planiceps (Owen, 1859) from the Karoo Basin, South 657 Africa. Palaeontology.

658 Case TJ. 1978. Speculations on the growth rate and reproduction of some dinosaurs. 659 Paleobiology 4:320-328.

660 Castanet J, Croci S, Aujard F, Perret M, Cubo J, Margerie de E. 2004. Lines of arrested growth 661 in bone and age estimation in a small primate: Microcebus murinus. Journal of Zoology $662 \quad 263: 31-39$.

663 Chinsamy A, Abdala NF. 2008. Paleobiological implications of the bone microstructure of South 664 American traversodontids (Therapsida: Cynodontia). South African Journal of Science 665 $104: 225-230$. 
666 Chinsamy A, Hurum JH. 2006. Bone microstructure and growth patterns of early mammals. Acta 667 Palaeontologica Polonica 51:325-338.

668 Chinsamy-Turan A. 2005. The Microstructure of Dinosaur Bone: Deciphering Biology with Fine 669 Scale Techniques. Baltimore: Johns Hopkins University Press.

670 Chinsamy-Turan A, Hurum JH. 2012. The radiation, bone histology, and biology of early

671 mammals. In: Chinsamy-Turan A, ed. Forerunners of mammals: radiation, histology, 672 biology. Bloomington: Indiana University Press, 249-270.

673 Clark JM, Hopson JA. 1985. Distinctive mammal-like reptile from Mexico and its bearing on the 674 phylogeny of the Tritylodontidae. Nature 315:398-400.

675 Cormack D. 1987. Ham `s Histology. New York: Lippincott.

676 Crompton AW. 1955. On some Triassic cynodont from Tanganyika. Proceeding of the 677 Zoological Society of London 125:617-669.

678 Crompton AW, Owerkowicz T, Bhullar B-AS, Musinsky C. 2017. Structure of the nasal region 679 of non-mammalian cynodonts and mammaliaforms: speculations on the evolution of 680 mammalian endothermy. Journal of Vertebrate Paleontology e1269116. DOI:

$681 \quad 10.1080 / 02724634.2017 .1269116$.

682 Francillon-Vieillot H, Buffrénil de V, Castanet J, Geraudie J, Meunier FJ, Sire JY, Zylberberg L, 683 Ricqlès de A. 1990. Microstructure and mineralization of vertebrate skeletal tissues. In: 684 Carter JG, ed. Skeletal Biomineralization: Patterns, Processes and Evolutionary Trends. 685 New York: Van Nestrand Reinhold, 471-548.

686 Gaetano LC, Abdala F, Govender R. 2017. The postcranial skeleton of the Lower Jurassic 687 Tritylodon longaevus from southern Africa. Ameghiniana 54(1):1-35. 
688 Gow CE. 1980. The dentitions of the Tritheledontidae (Therapsida: Cynodontia). Proceedings of 689 the Royal Society of London B 208:461-481.

690 Gradstein FM, Ogg JG, Hilgen FJ. 2012. On the geologic time scale. Newsletters on Stratigraphy $691 \quad 45: 171-188$.

692 Groenewald GH, Welman J, MacEachern JA. 2001. Vertebrate burrow complexes from the Early 693 Triassic Cynognathus Zone (Driekoppen Formation, Beaufort Group) of the Karoo Basin, 694 South Africa. Palaios 16:148-160.

695

696

697

698

699

700

701

702

703

704

705

706

707

708

709

710

Hopson JA. 2012. The role of foraging mode in the origin of therapsids: Implications for the origin of mammalian endothermy. Fieldiana Life and Earth Sciences 5:126-148.

Hopson JA, Kitching JW. 2001. A probainognathian cynodont from South Africa and the phylogeny of nonmammalian cynodonts. Bulletin of the Museum of Comparative Zoology 156:5-35.

Horn BLD, Melo TM, Schultz CL, Philipp RP, Kloss HP, Goldberg K. 2014. A new third-order sequence stratigraphic framework applied to the Triassic of the Paraná Basin, Rio Grande do Sul, Brazil, based on structural, stratigraphic and paleontological data. Journal of South American Earth Sciences 55:123-132.

Hutton JM. 1986. Age determination of living Nile crocodiles from the cortical stratification of bone. Copeia 2:332-341.

Jenkins FA. 1971. The postcranial skeleton of African cynodonts. Bulletin Peabody Museum of Natural History, Yale University 36:1-216.

Kammerer CR. 2016. A new taxon of cynodont from the Tropidostoma Assemblage Zone (upper Permian) of South Africa, and the early evolution of Cynodontia. Palaeontology 2:387-397. Kemp TS. 2005. The origin and evolution of mammals. Oxford: Oxford University Press. 
711 Kielan-Jaworowska Z. 1970. New Upper Cretaceous multituberculate genera from Bayn Dzak,

712 Gobi Desert. Palaeontologica Polonica 21:35-49.

713 Kielan-Jaworowska Z. 1974. Multituberculate succession in the Late Cretaceous of

714 the Gobi Desert (Mongolia). Palaeontologica Polonica 30:23-44.

715 Kielan-Jaworowska Z, Cifelli CL, Luo ZX. 2004. Mammals from the age of dinosaurs. New

$716 \quad$ York: New York University Press.

717 Köhler M, Marín-Moratalla N, Jordana X, Aanes R. 2012. Seasonal bone growth and physiology

718 in endotherms shed light on dinosaur physiology. Nature 487:358-361.

719 Langer MC. 2005. Studies on continental Late Triassic tetrapod biochronology. II. The

720 Ischigualastian and a Carnian global correlation. Journal of South American Earth Sciences

$721 \quad 19: 219-239$.

722 Langer MC, Ramezani J, Da Rosa ÁAS. 2018. U-Pb age constraints on dinosaur rise from south 723 Brazil. Gondwana Research 57:133-140.

724 Lee AH, Werning S. 2008. Sexual maturity in growing dinosaurs does not fit reptilian growth models. Proceedings of the National Academy of Sciences U S A Biological Sciences

726 105:582-587.

727

728

729

730

731

Lee AH, Huttenlocker AK, Padian K, Woodward HN. 2013. The biology of bone. In: Padian K, Lamm E-T, eds. Bone histology of fossil tetrapods. Advancing methods, analysis, and interpretation. Berkeley: University of California Press, 217-252.

Liu J, Olsen PE. 2010. The phylogenetic relationships of Eucynodontia (Amniota, Synapsida). Journal of Mammalian Evolution 17:151-176. 
732 Luo Z-X. 1994. Sister-group relationships of mammals and transformations of diagnostic 733 mammalian characters. In: Fraser NC, Sues H-D, eds. In the Shadow of the Dinosaurs. 734 Cambridge: Cambridge University Press, 98-128.

735 Luo Z-X. 2007. Transformation and diversification in early mammal evolution. Nature

736

737

738

739

740

741

742

743

744

745

746

747

748

749

750

751

752 450:1011-1019.

Luo Z-X, Crompton AW, Sun A-L. 2001. A new mammaliaform from the Early Jurassic and evolution of mammalian characteristics Science 292:1535-1540.

Magwene PM. 1993. What's bred in the bone: histology and cross-sectional geometry of mammal-like reptile long bones-evidence of changing physiological and biomechanical demands. M.S. Thesis, Harvard University.

Martínez R, Apaldetti C, Alcober OA, Colombi CE, Sereno PC, Fernández E, Santi Malnis P, Correa GA, Abelín D. 2013. Vertebrate succession in the Ischigualasto Formation. Society of Vertebrate Paleontology Memoir 12, Journal of Vertebrate Paleontology 32:10-30.

Martinelli AG. 2017. Contribuição ao conhecimento dos cinodontes probainognátios (Therapsida, Cynodontia, Probainognathia) do Triássico da América do Sul e seu impacto na origem dos Mammaliaformes. D. Phil. Universidade Federal do Rio Grande do Sul.

Martinelli AG, Bonaparte JF. 2011. Postcanine replacement in Brasilodon and Brasilitherium (Cynodontia, Probainognathia) and its bearing in cynodont evolution. In: Calvo J, Porfiri J, González Riga B, Dos Santos D, eds. Dinosaurios y Paleontología desde América Latina, Anales del III Congreso Latinoamericano de Paleontología (Neuquén, 2008). Mendoza: Editorial de la Universidad Nacional de Cuyo, 179-186. 
753 Martinelli AG, Rougier GW. 2007. On Chaliminia musteloides Bonaparte (Cynodontia,

754 Tritheledontidae) and the phylogeny of the Ictidosauria. Journal of Vertebrate Paleontology

$755 \quad 27: 442-460$.

756 Martinelli AG, Soares MB. 2016. Evolution of South American cynodonts. Contribuciones del

757 Museo Argentino de Ciencias Naturales “Bernardino Rivadavia” 6:183-197.

758 Martinelli AG, Soares MB, Schwanke C. 2016. Two new cynodonts (Therapsida) from the

759 Middle-Early Late Triassic of Brazil and comments on South American probainognathians.

$760 \quad$ PLOS ONE 11:e0162945.

761 Martinelli AG, Bonaparte JF, Schultz CL, Rubert R. 2005. A new tritheledontid (Therapsida,

762 Eucynodontia) from the Late Triassic of Rio Grande do Sul (Brazil) and its phylogenetic

763 relationships among carnivorous non-mammalian eucynodonts. Ameghiniana 42:191-208.

764 Martinelli AG, Eltink E, Da-Rosa ÁAS, Langer MC. 2017a. A new cynodont (Therapsida) from

765 the Hyperodapedon Assemblage Zone (upper Carnian-Norian) of southern Brazil improves

766 the Late Triassic probainognathian diversity. Papers in Palaeontology 3:401-423.

767 Martinelli AG, Soares MB, Oliveira TV, Rodrigues PG, Schultz CL. 2017b. The Triassic

768 eucynodont Candelariodon barberenai revisited and the early diversity of stem

769 prozostrodontians. Acta Palaeontologica Polonica 62:527-542.

770 Matsuoka H, Kusuhashi N, Corfe IJ. 2016. A new Early Cretaceous tritylodontid (Synapsida,

771 Cynodontia, Mammaliamorpha) from the Kuwajima Formation (Tetori Group) of central

772 Japan. Journal of Vertebrate Paleontology 36:e1112289.

773 Miller JS, Zammuto RM. 1983. Life histories of mammals: An analysis of life tables. Ecology

$774 \quad 64: 631-635$. 
775 Montoya-Sanhueza G, Chinsamy A. 2017. Long bone histology of the subterranean rodent 776 Bathyergus suillus (Bathyergidae): ontogenetic pattern of cortical bone thickening. Journal $777 \quad$ of Anatomy 230: 203-233.

778 Nesterenko V, Ohdachi SD. 2001. Postnatal growth and development in Sorex unguiculatus. $779 \quad$ Mammal Study 26:145-148.

780 Oliveira TV, Soares MB, Schultz CL. 2016. Trucidocynodon riograndensis gen. nov. et sp. nov. 781 (Eucynodontia), a new cynodont from the Brazilian Upper Triassic (Santa Maria $782 \quad$ Formation). Zootaxa 2382:1-71.

783 Oliveira TV, Martinelli AG, Soares MB. 2011. New material of Irajatherium hernandezi Martinelli, Bonaparte, Schultz and Rubert 2005 (Eucynodontia, Tritheledontidae) from the Upper Triassic (Caturrita Formation, Paraná Basin) of Brazil. Paläontologische Zeitschrift 786 85:67-82.

787

788

789

790

791

792

793

794

795

796

797

O’Meara RN, Asher RJ. 2016. The evolution of growth patterns in mammalian versus nonmammalian cynodonts. Paleobiology 42:439-464.

Owens FN, Dubeski P, Hanson CF. 1993. Factors that alter the growth and development of ruminants. Journal of Animal Science 71:3138-3150.

Promislow DEL, Harvey PH. 1990. Living fast and dying young: A comparative analysis of lifehistory variation among mammals. Journal of Zoology London 220:417-9437.

Ray S, Botha J, Chinsamy A. 2004. Bone histology and growth patterns of some nonmammalian therapsids. Journal of Vertebrate Paleontology 24:634-648.

Ricqlès de A. 1969. Recherches paléohistologiques sur les os longs des Tétrapodes. II, Quelques observations sur la structure des longs des Thériodontes. Annales de Paléontologie (Vertébrés) 55:1-52. 
798 Ricqlès de A, Meunier FJ, Castanet J, Francillon-Vieillot H. 1991. Comparative microstructure 799 of bone. In: Hall BK, ed. Bone, Volume 3: Bone matrix and bone specific products. Boca 800 Raton: CRC Press. 1-77.

801 Rodrigues PG, Ruf I, Schultz CL. 2013. Digital reconstruction of the otic region and inner ear of 802 the non-mammalian cynodont Brasilitherium riograndensis (Late Triassic, Brazil) and its 803 relevance to the evolution of the mammalian ear. Journal of Mammalian Evolution 20:291$804 \quad 307$.

805 806

807

808

809

810

811

812 813

814

815 816

817 818 819

Rodrigues PG, Ruf I, Schultz CL. 2014. Study of a digital cranial endocast of the nonmammaliaform cynodont Brasilitherium riograndensis (Later Triassic, Brazil) and its relevance to the evolution of the mammalian brain. Paläontologische Zeitschrift 88:329352.

Ruf I, Maier W, Rodrigues PG, Schultz CL. 2014. Nasal anatomy of the non-mammaliaform cynodont Brasilitherium riograndensis (Eucynodontia, Therapsida) reveals new insight into mammalian evolution. The Anatomical Record 297:2018-2030.

Ruta M, Botha-Brink J, Mitchell SA, Benton MJ. 2013. The radiation of cynodonts and the ground plan of mammalian morphological diversity. Proceedings of the Royal Society B 280: 20131865. DOI: 10.1098/rspb.2013.1865.

Soares MB, Martinelli AG, Oliveira TV. 2014. A new prozostrodontian cynodont (Therapsida) from the Late Triassic Riograndia Assemblage Zone (Santa Maria Supersequence) of Southern Brazil. Anais da Academia Brasileira de Ciências 86:1673-1691.

Soares MB, Schultz CL, Horn BLD. 2011. New information on Riograndia guaibensis Bonaparte, Ferigolo and Ribeiro, 2001 (Eucynodontia, Tritheledontidae) from the Late 
820 Triassic of southern Brazil: anatomical and biostratigraphic implications. Anais da 821 Academia Brasileira de Ciências 83:329-354.

822 Sues H-D. 1986. The skull and dentition of two tritylodontid synapsids from the Lower Jurassic 823 of western North America. Bulletin of the Museum of Comparative Zoology 151:217-268.

824 Stein K, Prondvai E. 2013. Rethinking the nature of fibrolamellar bone: an integrative biological 825 revision of sauropod plexiform bone formation. Biological Reviews 89:24-47.

826 Thomason JJ, Russell AP. 1986. Mechanical factors in the evolution of the mammalian 827 secondary palate: a theoretical analysis. Journal of Morphology 189:199-213.

828 Veiga FH, Botha-Brink J, Soares MB. 2018. Osteohistology of the non-mammaliaform 829 traversodontids Protuberum cabralense and Exaeretodon riograndensis from southern 830 Brazil. Historical Biology. DOI: 10.1080/08912963.2018.1441292.

831 Woodward HN, Horner JR, Farlow JO. 2011. Osteohistological evidence for determinate growth 832 in the American alligator. Journal of Herpetology 45:339-342.

833 Zerfass H, Lavina EL, Schultz CL, Garcia AJV, Faccini UF, Chemale F Jr. 2003. Sequence 834 stratigraphy of continental Triassic strata of Southernmost Brazil: a contribution to 835 Southwestern Gondwana palaeogeography and palaeoclimate. Sedimentary Geology $836 \quad 161: 85-105$. 


\section{Figure 1}

Acquisition of mammalian features mapped onto a Triassic-Jurassic cynodont phylogenetic tree.

Growth patterns are known for those taxa shown in white and reveal high growth rates throughout the cynodont lineage. Taxa examined in this study appear in blue. Colors indicate increasing acquisition of mammalian characteristics during cynodont evolution (from yellow to red). Arrows indicate the possible timing of the evolution of mammalian characteristics for which morphological or behavioral data are known. (1) differentiation of vertebral column resulting in improved agility (Kemp, 2005), (2) bony secondary palate, allowing for more continuous ventilation (Bennett and Ruben, 1986), (3) increased tooth differentiation and improved tooth occlusion, allowing radiation into new ecology niches, here indicated by the Gomphodontia (Abdala and Ribeiro, 2010), (4) extended parental care, suggesting increased parental investment in young (Groenwald, Welman and MacEachern, 2001), (5) loss of pineal foramen indicating increasing thermoregulatory and reproductive control (Benoit et al., 2016a), (6) possible evolution of maxillary vibrissae indicating improved sensory structures (Benoit et al., 2016b), (7) ossified maxillary turbinates indicating efficient counter current exchange system for the conservation of heat and water (Crompton et al., 2017). Phylogeny taken from Ruta et al. (2013) and Martinelli et al. (2017a, b). Dates taken from Gradstein, Ogg and Hilgen (2012) and Martinelli et al. (2017a, b). Abbreviations: ANS, Anisian; CRN, Carnian; E.T., Early Triassic; HET, Hettangian; I, Induan; LAD, Ladinian; M., Middle; OLE, Olenekian; PLB, Pliensbachian; RHT, PTB, Permo-Triassic Boundary; Rhaetian; SIN, Sinemurian. 


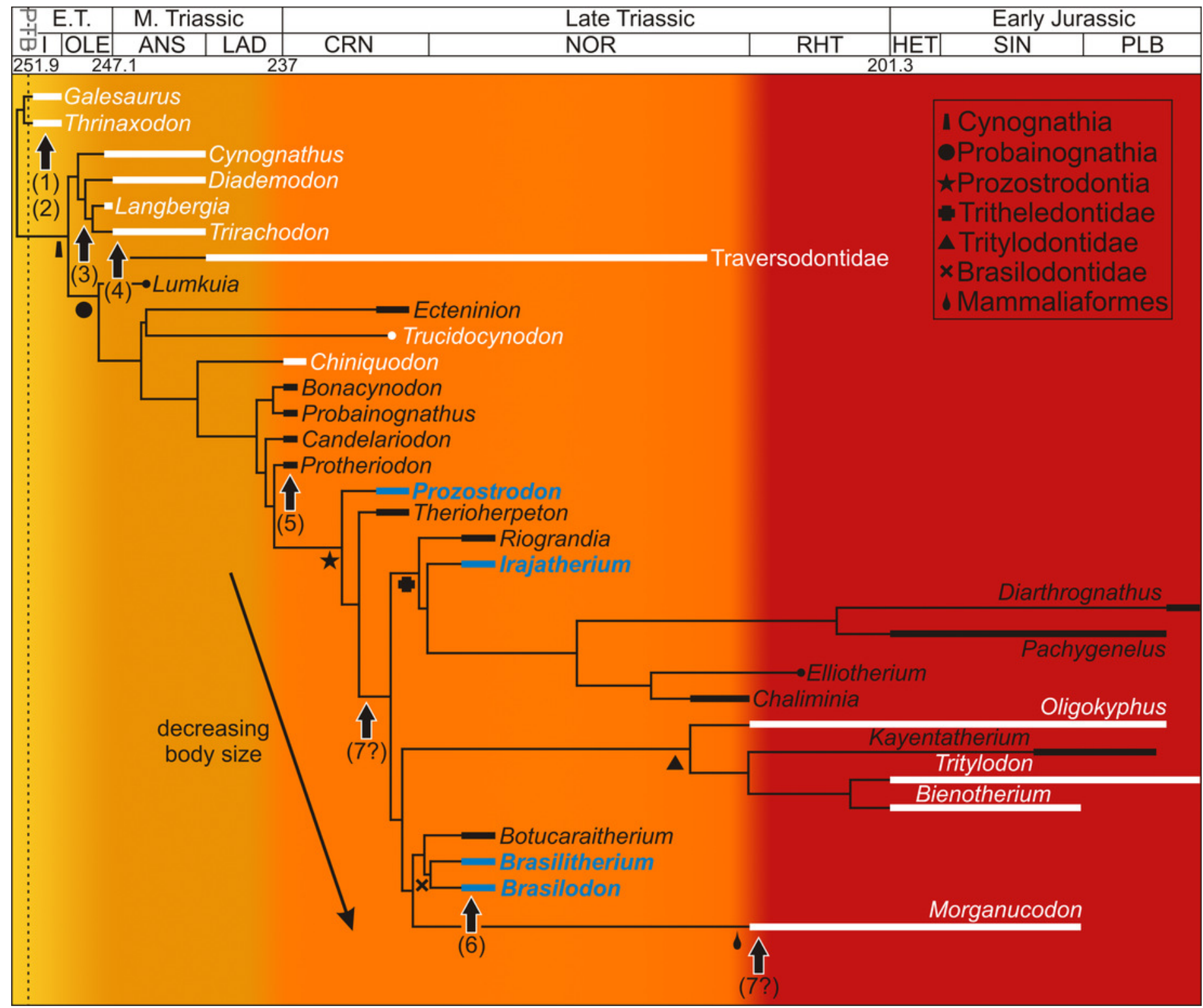




\section{Figure 2}

Limb bone osteohistology of Prozostrodon brasiliensis UFRGS-PV-248-T.

(A) Whole cross-section of humerus UFRGS-PV-248a-T in CPL showing a relatively thick cortex and two regions of parallel-fibered bone (arrowheads). (B) High magnification of the humerus showing alternating fibrolamellar and parallel-fibered bone. Arrowhead indicates a LAG within the parallel-fibered bone region. (C) Sharpey's fibers (arrows) in the humerus indicating an area of muscle insertion and a LAG (arrowhead) in the mid-cortex. (D) Whole cross-section of femur UFRGS-PV-248b-T showing a relatively thick cortex and a LAG (arrowhead) running through the wide zone of parallel-fibered bone. (E) High magnification of the femur showing alternating fibrolamellar and parallel-fibered bone with an annulus (arrowhead). (F) Peripheral reticular vascular canals in the fibrolamellar bone of the femur. Arrowhead indicates an annulus. (G) Longitudinal section of the femur showing Sharpey's fibers (arrows) indicating an area of muscle insertion. Abbreviations: FLB, fibrolamellar bone; MC, medullary cavity; PFB, parallel-fibered bone; PO, primary osteons; RC, resorption cavities; RVC, radiating vascular canals. Scale bars equal $100 \mu \mathrm{m}$, apart from $A$ and $D$, which equal 1000 $\mu \mathrm{m}$. 

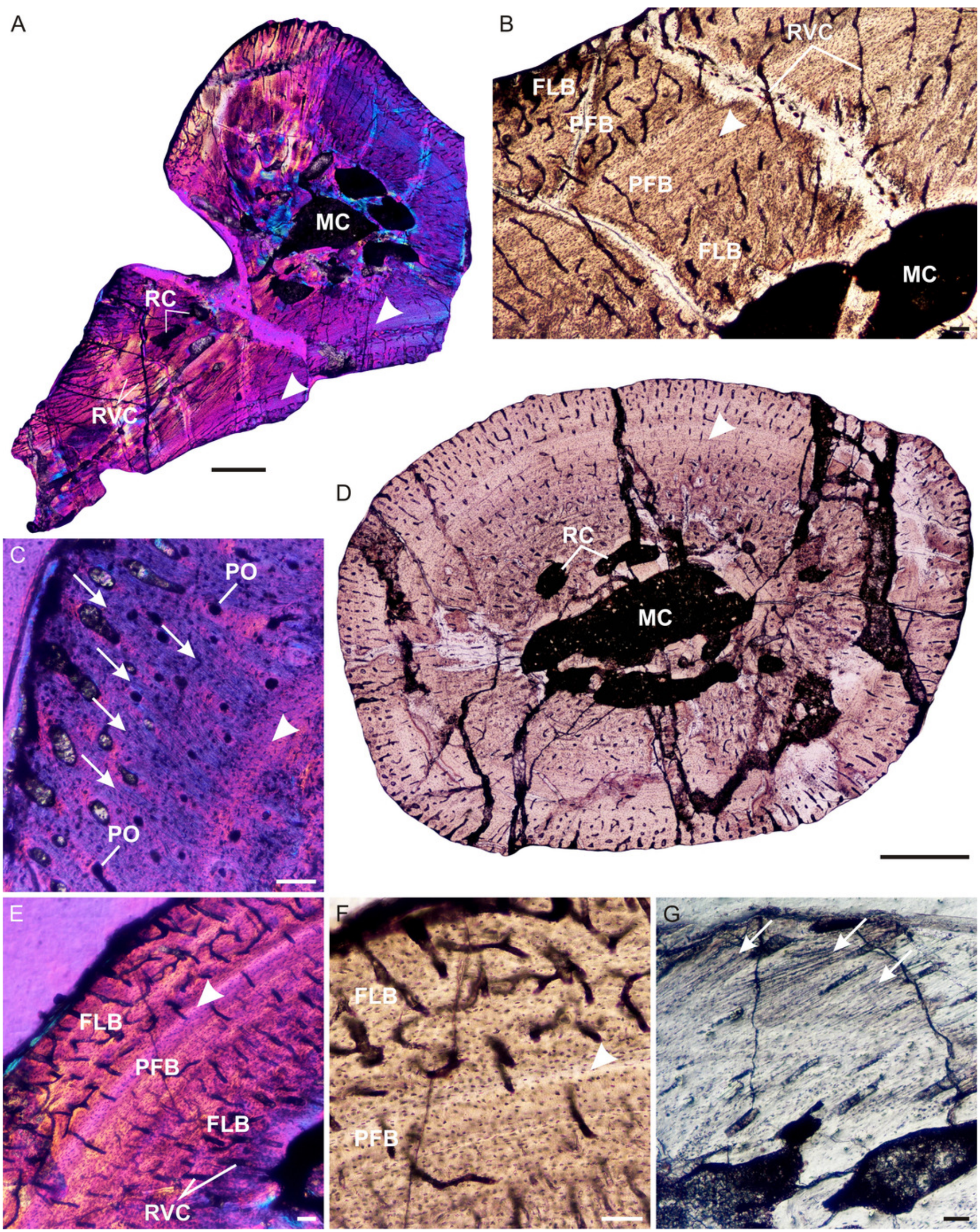


\section{Figure 3}

Humeral osteohistology of Irajatherium hernandezi UFRGS-PV-1072-T.

(A) Whole cross-section showing a relatively thick cortex. A LAG (arrowhead) marks the beginning of a slower growing zone of parallel-fibered and lamellar-zonal bone. (B) Midcortical fibrolamellar bone is followed by lamellar-zonal bone with at least one LAG, possibly more (arrowheads). (C) High magnification showing longitudinally-oriented primary osteons in a woven-fibered matrix. (D) Another region of the outer cortex showing lamellarzonal bone (brackets) with several possible LAGs (arrowheads). Abbreviations: FLB, fibrolamellar bone; LZB, lamellar-zonal bone; MC, medullary cavity; PFB, parallel-fibered bone; PO, primary osteon; RC, resorption cavity; RVC, radial vascular canal. Scale bars equal $100 \mu \mathrm{m}$.
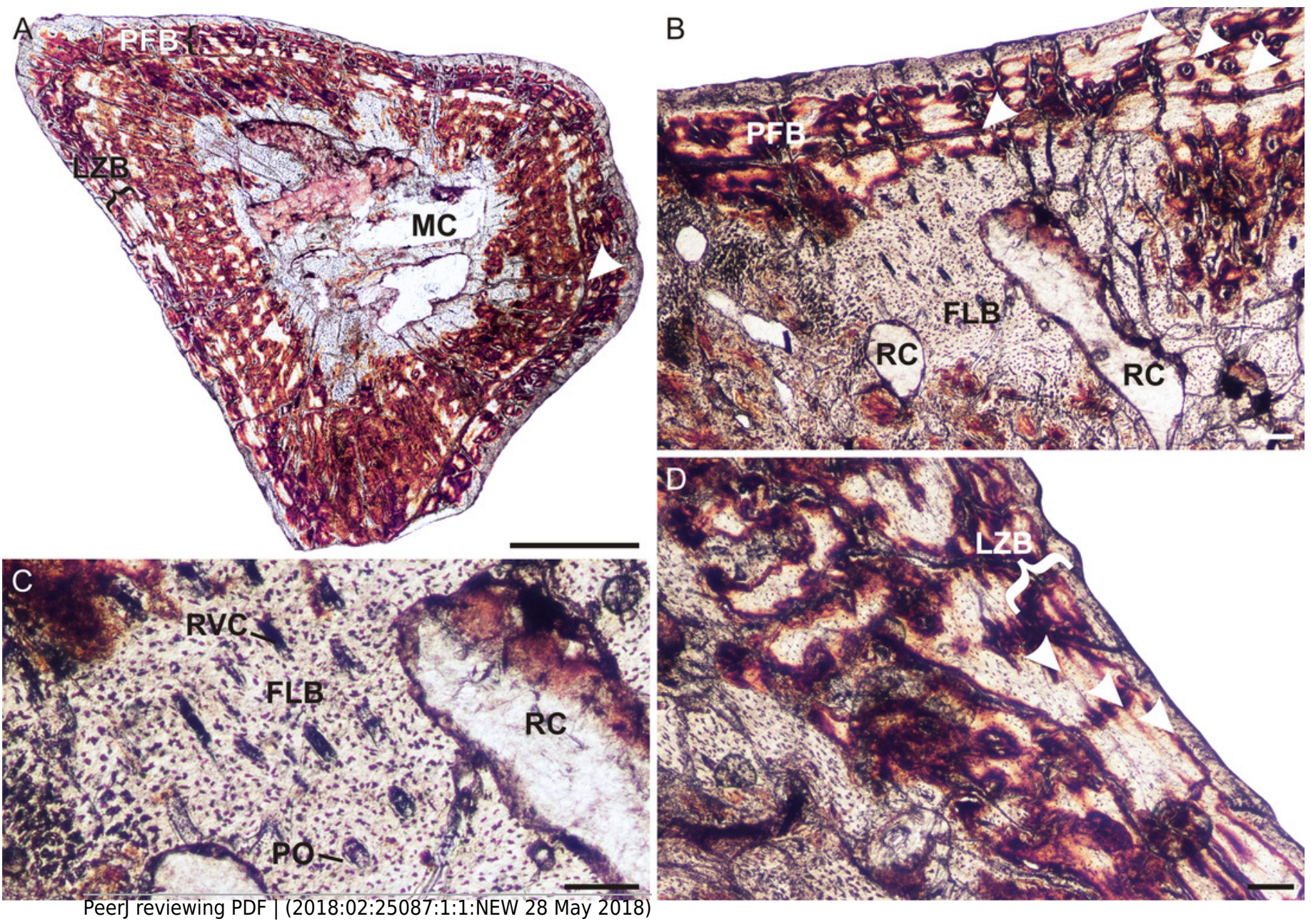


\section{Figure 4}

Limb bone osteohistology of Brasilitherium riograndensis.

(A) Radius UFRGS-PV-1308a-T showing poorly vascularized parallel-fibered bone tissue. (B) Ulna UFRGS-PV-1308b-T showing lamellar bone. (C) Femur UFRGS-PV-1308c-T showing patches of woven-fibered, parallel-fibered and lamellar bone. (D) High magnification of the femur showing haphazardly arranged osteocyte lacunae (left) and more organized osteocyte lacunae (right). (E) Tibia UFRGS-PV-1308d-T showing patches of woven-fibered and parallelfibered bone. (F) High magnification of the tibia showing several poorly developed primary osteons (arrows). (G) Fibula UFRGS-PV-1308e-T showing avascular lamellar bone. (H) Femur UFRGS-PV-1043-T in CPL showing a mid-cortical LAG (arrowhead). (I) High magnification of the LAG (arrowhead) followed by slowly forming lamellar bone. (J) High magnification of femur UFRGS-PV-1043-T showing haphazardly arranged osteocyte lacunae and a few small secondary osteons (arrows). Abbreviations: EB, endosteal bone; MC, medullary cavity; PFB, parallel-fibered bone; LB, lamellar bone; WFB, woven-fibered bone. Scale bars $=100 \mu \mathrm{m}$. 

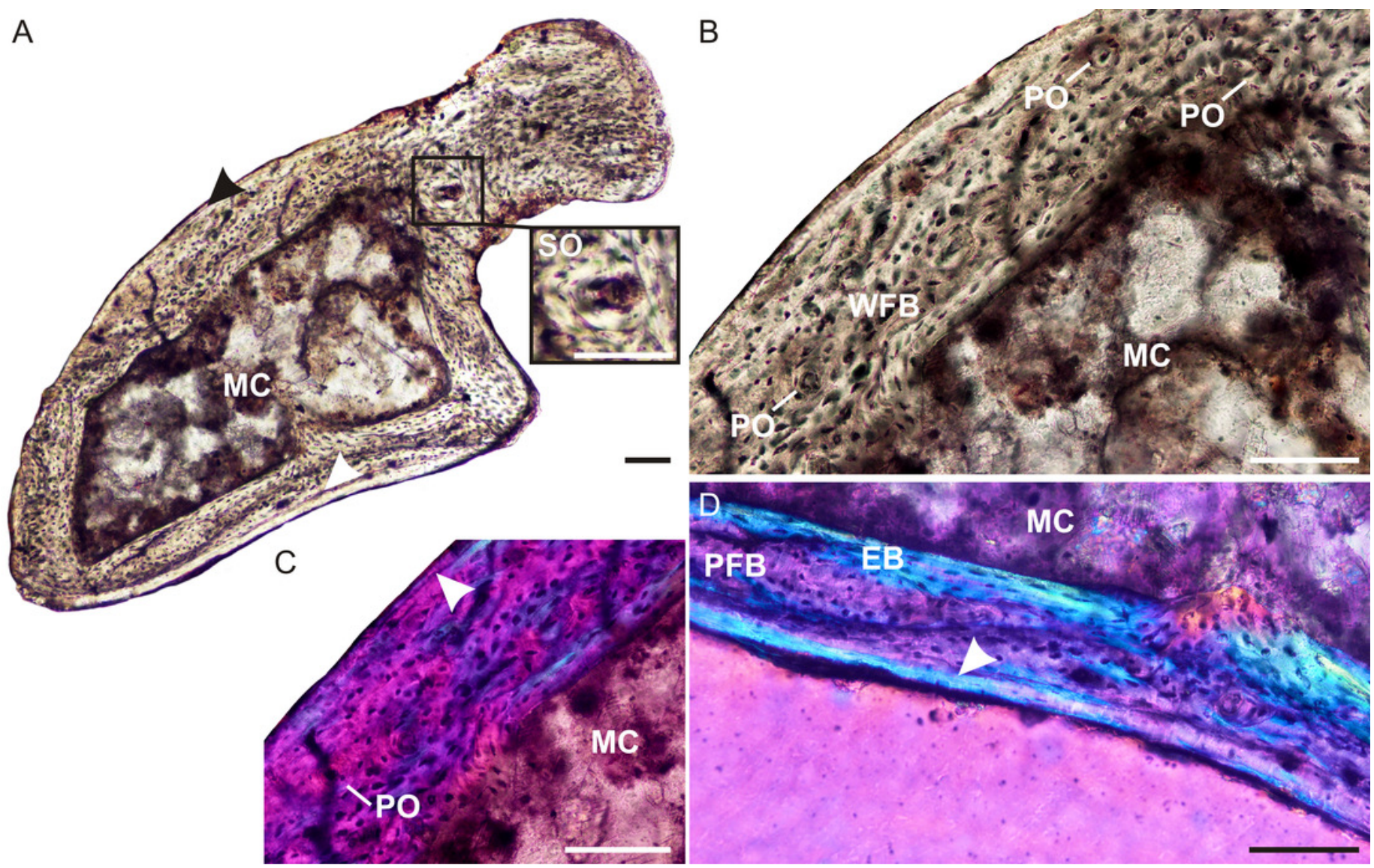


\section{Figure 5}

Limb bone osteohistology of Brasilitherium riograndensis.

(A) Radius UFRGS-PV-1308a-T showing poorly vascularized parallel-fibered bone tissue. (B) Ulna UFRGS-PV-1308b-T showing lamellar bone, arrowhead indicates a possible growth mark. (C) Femur UFRGS-PV-1308c-T showing patches of woven-fibered, parallel-fibered and lamellar bone. (D) High magnification of the femur showing haphazardly arranged osteocyte lacunae (left) and more organized osteocyte lacunae (right). (E) Tibia UFRGS-PV-1308d-T showing patches of woven-fibered and parallel-fibered bone. (F) High magnification of the tibia showing several poorly developed primary osteons. (G) Fibula UFRGS-PV-1308e-T showing avascular lamellar bone. (H) Femur UFRGS-PV-1043-T in CPL showing a mid-cortical LAG (arrowhead). (I) High magnification of the LAG (arrowhead) followed by slowly forming lamellar bone. (J) High magnification of femur UFRGS-PV-1043-T showing haphazardly arranged osteocyte lacunae and a few small secondary osteons. Abbreviations: EB, endosteal bone; MC, medullary cavity; PFB, parallel-fibered bone; LB, lamellar bone; PO, primary osteon; SO, secondary osteon; WFB, woven-fibered bone. Scale bars equal $100 \mu \mathrm{m}$. 

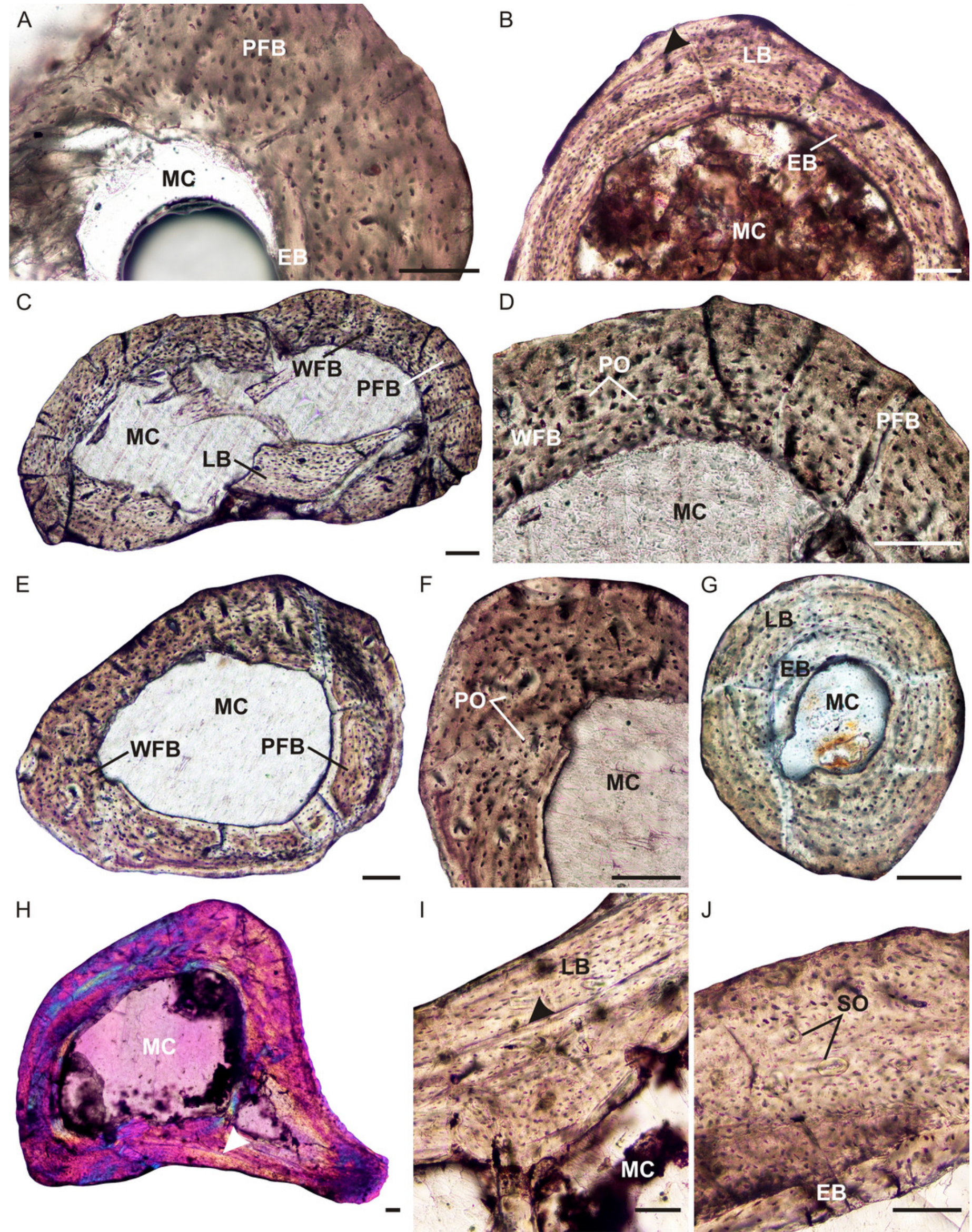